TITLE:

\title{
CONTRIBUTIONS TO JAPANESE ASCIDIAN FAUNA IV. -NOTES ON SOME ASCIDIANS COLLECTED IN OSAKA BAY (1)-
}

$\operatorname{AUTHOR(S):~}$

Tokioka, Takasi

CITATION:

Tokioka, Takasi. CONTRIBUTIONS TO JAPANESE ASCIDIAN FAUNA IV. -NOTES ON SOME ASCIDIANS COLLECTED IN OSAKA BAY (1)-. PUBLICATIONS OF THE SETO MARINE BIOLOGICAL LABORATORY 1951, 1(4): 169-182

\section{ISSUE DATE:}

1951-05-31

URL:

http://hdl.handle.net/2433/174447

RIGHT: 


\title{
CONTRIBUTIONS TO JAPANESE ASCIDIAN FAUNA IV.
}

\author{
NOTES ON SOME ASCIDIANS COLLECTED IN OSAKA BAY (1)*
}

TAKASI TOKIOKA

With Plate XI and 8 Text-figures

The present material consists of 14 species collected by Mr. R. IsIBAsi at Ozaki on the east coast of Osaka Bay, exactly midway between Osaka and Wakayama. I wish to express here my hearty thanks to Mr. IsIBAsI for his kindness in offerring me the material, and to Prof. T. Komal for his incessant encouragement and kind guidance.**

\section{Distaplia japonica - n. sp.}

(Fig. 1)

Two colonies incrusting Sargassum, preserved in formalin. Test semitramsparent, steelblue in colour and sprinkled with white zooids in one colony, while it is grayish white and sprinkled with yellowish brown zooids in the other. Thickness of colony $2-3 \mathrm{~mm}$. System rather distinct; smaller systems consist of ca. 10 zooids and $3-4 \mathrm{~mm}$ in diameter, larger ones contain 20-30 zooids and reach $12 \mathrm{~mm}$ along the long axis.

Thorax: Length about $1 \mathrm{~mm}$ in strongly contracted condition. Abdomen slightly larger than the contracted thorax. Branchial aperture 6-lobed. Atrial languet conspicuous; tip simple or divided into three lobes.

Abdomen: Oesophagus enters the stomach horizontally. Stomach ovoid, with ca. 15 irregular faint longitudinal plications on the surface. Gonad in the intestinal loop. Testicular follicles less than 10 , usually $6-9$ in number. Pericardium on the opposite side of the gonad. Trunk of larva about $1 \mathrm{~mm}$ in length.

Remarks: D. occidentalis BANCRofT, distributed along the western coast of North America, has the gonad situated posterior to the intestinal loop in

* Contributions from the Seto Marine Biological Laboratory, No. 158.

** A part of the expense for the study was defrayed from the grant by the Ministry of Education.

Publ. Seto Mar. Biol. Lab., I (4) 1951. 


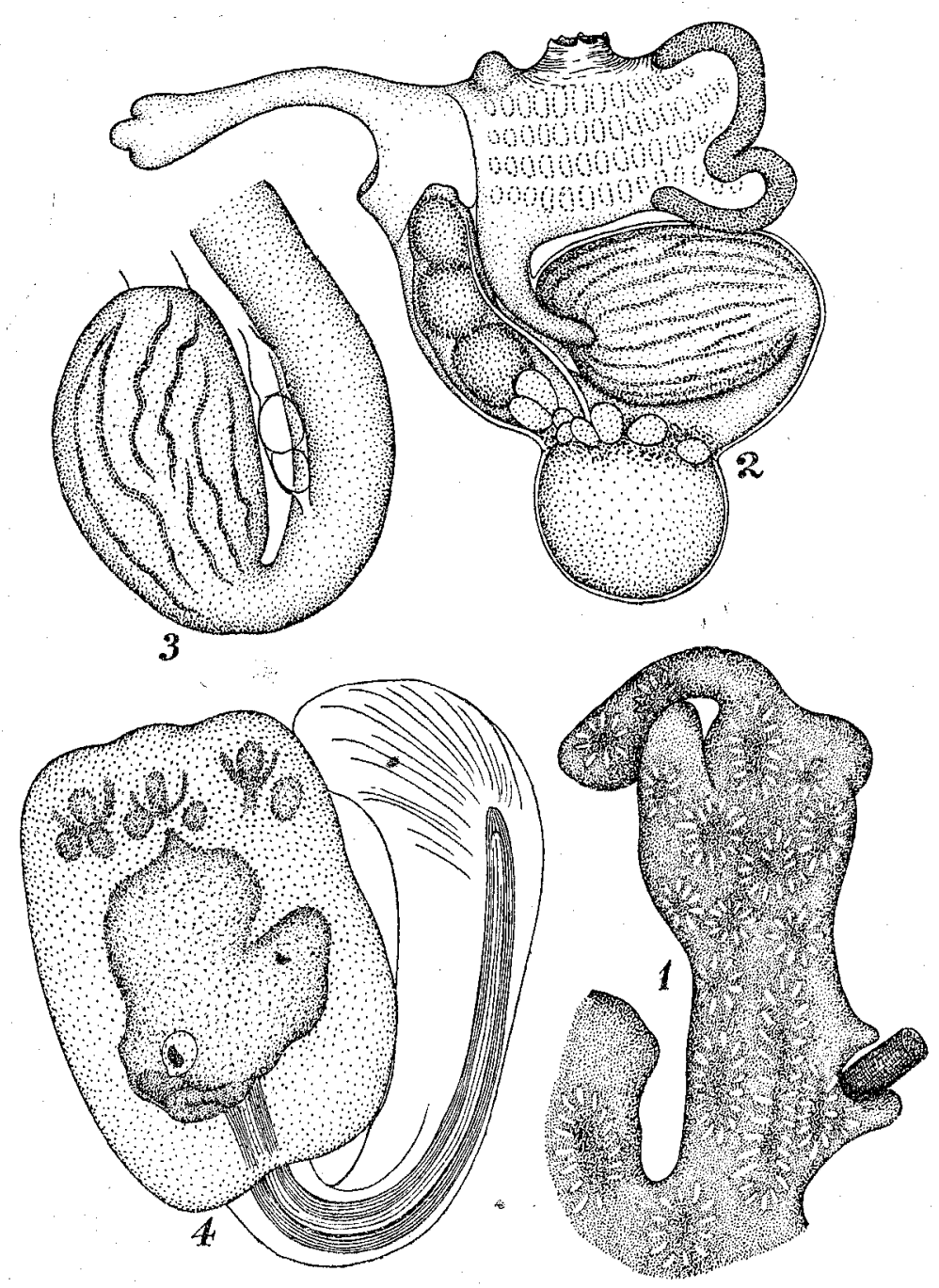

Fig. 1. Distaplia japonica n. sp. 1-A part of colony, $\times 1.5 ; 2-$ Zooid, $\times 45$; 3-Abdomen, $\times 45 ; 4-$ Larva, $\times 45$.

adult specimens. D. stylifera (KowALEvsky), a tropical species, resembles the present new species in the appearance of the stomach with slight plications, but the mushroom-like shape of the colony and the presence of the post-abdomen filled with the gonad separate the former distinctly from the latter.

D. clavala (SARs), an arctic species, differs also from the present species in the shape of its colony which assumes a characteristic club-like form. 


\section{Ciona intestinalis (LINNAEUS) 1767}

Several individuals attached on shells of Ostrea and Pinna.

\section{Ascidia divisa SLutTer 1898}

(Fig. 2)

Ascidia canaliculata SudTer (1885): Naturk. Tijolschr. Neder1. Ind., Vol. 45. Ascidia divisa Sluiter (1898): Zool. Jahrb. Syst., Vol. 11; Sluiter (1904)

Siboga-Exped. mon. 56 a; HarTmeyer (1906) Zool. Anz., Vol. 31.

Four specimens; the largest one measures $40 \mathrm{~mm}$ long $\times 25 \mathrm{~mm}$ wide, while the smallest one is $28 \mathrm{~mm}$ in length, with dorsomventral thickness $8-10 \mathrm{~mm}$. Body oval, siphons indistinct. Branchial aperture terminal, atrial aperture situated slightly anterior to the middle of the body. Test cartilaginous and

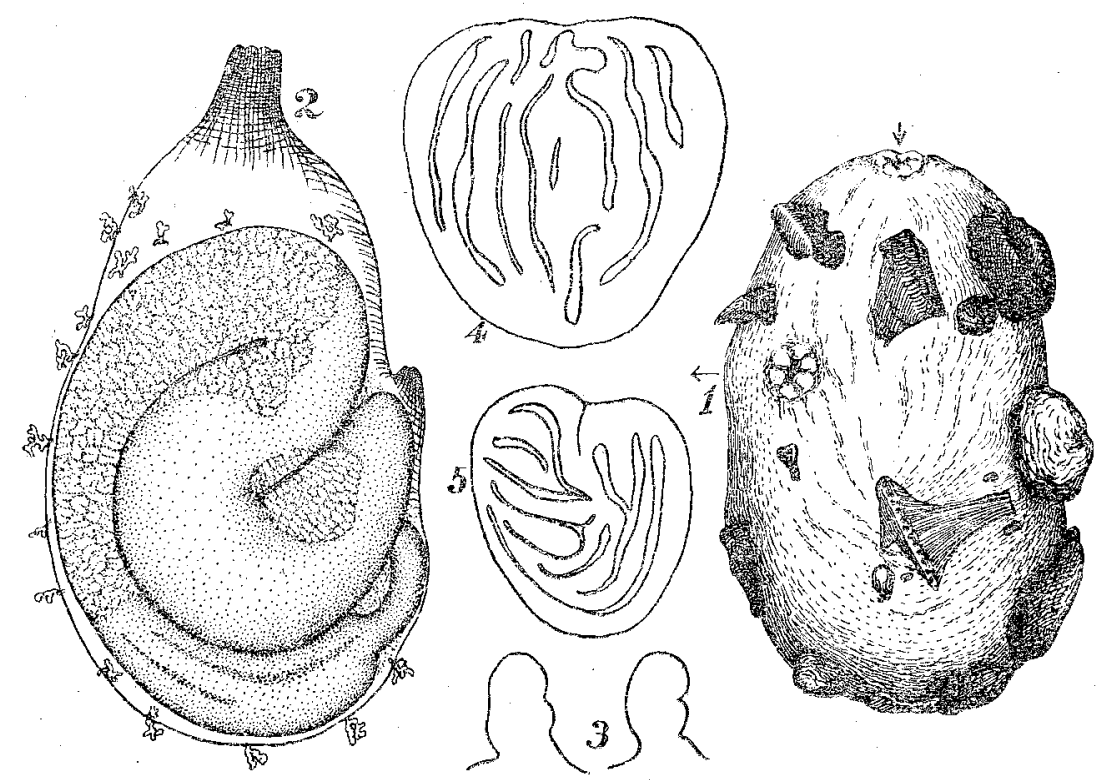

Fig. 2. Ascidia divisa StuiTER. 1-Right side of the entire animal; 2-Teft side of the mantle body; 3-Papillae supporting the inner longitudinal vessels, $\times 75 ; 4 \& 5$--Ciliated grooves.

semitransparent; the surface irregularly wrinkled and furnished with some grits or shell fragments, showing that these specimens lying on a gritty bottom, with their left side below. Mantle yellowish brown, except the left side 
which appears somewhat grayish-white on account of the alimentary canal showing through. Many minute vessels protrude out of the general contour of the mantle along its peripheral margin on its left side. Muscles restricted to the marginal portion on the right side only. Margin of branchial aperture divided into $7-8$ lobes, that of the atrial aperture into 6 lobes; the lobes are pectinate in some individuals. Both siphonal tubes very short.

Branchial sac: Inner longitudinal vessels ca. 32, transverse vessels $100-$ 140. Slight plications present. Four to five stigmata in a mesh. Margin of dorsal lamina with shallow and somewhat irregular notches; ribs present, but not protruding from the margin, Dorsal tubercle large; ciliated groove divided into numerous slits and has a complex configuration. Tentacles $40-60$, excluding minute ones.

Alimenta'y system: The anterior margin of the intestinal loop reaches midway between the bases of both apertures. Line- $\alpha$ (axis of the second intestinal loop) reached beyond the pyloric end of the stomach.

Remarks: Ascidia samea OKA resembles the present species in the arrangement of the mantie muscles. But, the formex shows much closer resemblance with As. sydneiensis STIMPSON in having rather simple ciliated groove. For the present, I am not certain of the identity of As. divisa to As. sydneionsis.

\section{Botryllus communis OKA 1927.}

(Fig. 3)

Many colonies attached to Sargassam. Test transparent, zooids purplishbrown in colour. System distinct.

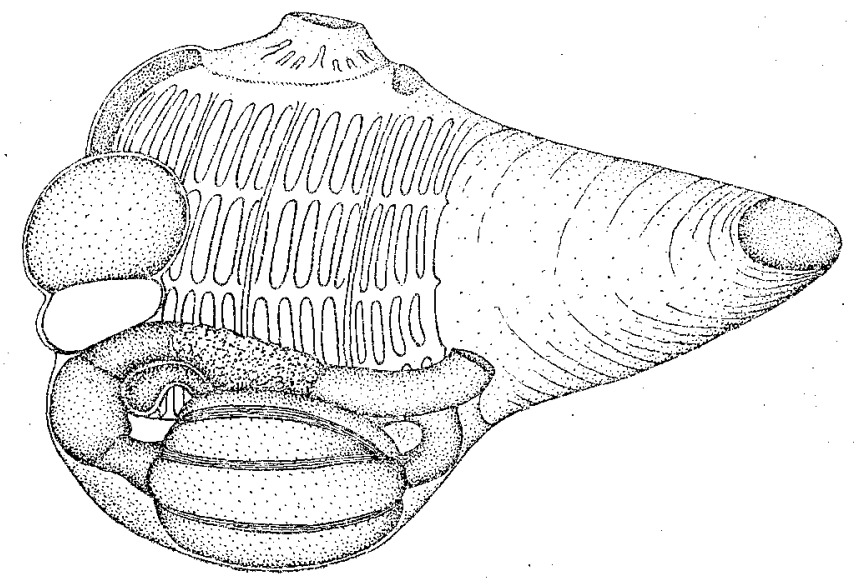

Figs 3. Fotrylla commmis OKA. Zovid. 
Zooid: Zooids nearly vertical and $1 \mathrm{~mm}$ in length. Stigmata arranged as: D $4 \quad 3-4 \quad 4-5 \mathrm{~V}$. The anterior margin of the intestinal loop reaches the middle of the third stigmata row, or posterior to it. Stomach with 8 plications.

Gonad: Testis is an ovoid mass situated close to the ventral side on the 3rd stigmata-row on the left side, and on the 4 th stigmata-row or posterior to that level on the right side. Ovary developes on the anterior side of the testis; often with a large mature ovum protruding out.

\section{Botrylloides violaceum OKA 1927}

Two small colonies $18 \times 7 \mathrm{~mm}$ and $9 \times 7 \mathrm{~mm}$ respectively in extent and both $2 \mathrm{~mm}$ in thickness, attached to a rock below the low-water mark, were found on March 241950 at Tannowa near Ozaki. Colour of zooids purplishbrown. Stomach with 9 plications.

\section{Symplegma reptans (OKA) 1927}

rit. Tokioka (1949): Publ, Seto Mar. Biol. Lab. Vol. 1, No. 2, pp. $49-51$.

Many colonies incrusting Sargassum. A small colony covers the carapace of a Leucosiid crab partly. Atrial tentacles present?

Branchial sac: Six to seven stigmata rows on the dorsal side and 7-8 on the ventral side.

Alimentary system: The anterior end of the intestinal loop does not reach the middle of the body. Stomach with $9-10$ plications. Pyloric coecum distinct.

La'va: $1.5 \mathrm{~mm}$ in length. Trunk $1 / 2.5-1 / 3$ the leigth of tail, elongate oval in shape and with 3 distinct attachment processes. No ampulla in the anterior part of the trunk.

\section{Polyzoa pacifica n. sp.}

(Fig. 4.)

Many individuals attached on Sargassum. Body 3-4 $\mathrm{mm}$ in length, oval in shape, and considerably depressed dorsomentraliy. Each ascidian is attached by the ventral side and connected one another with creeping stolons. Branchial aperture subterminal, atrial aperture near the middle of the body; both apertures round. Test sandy gray and very strong. Mantle dark brownish and considerably thick. An elongate vesicle, probably the endocarp, is present near the centre of the inner surface of the mantle on each side. 

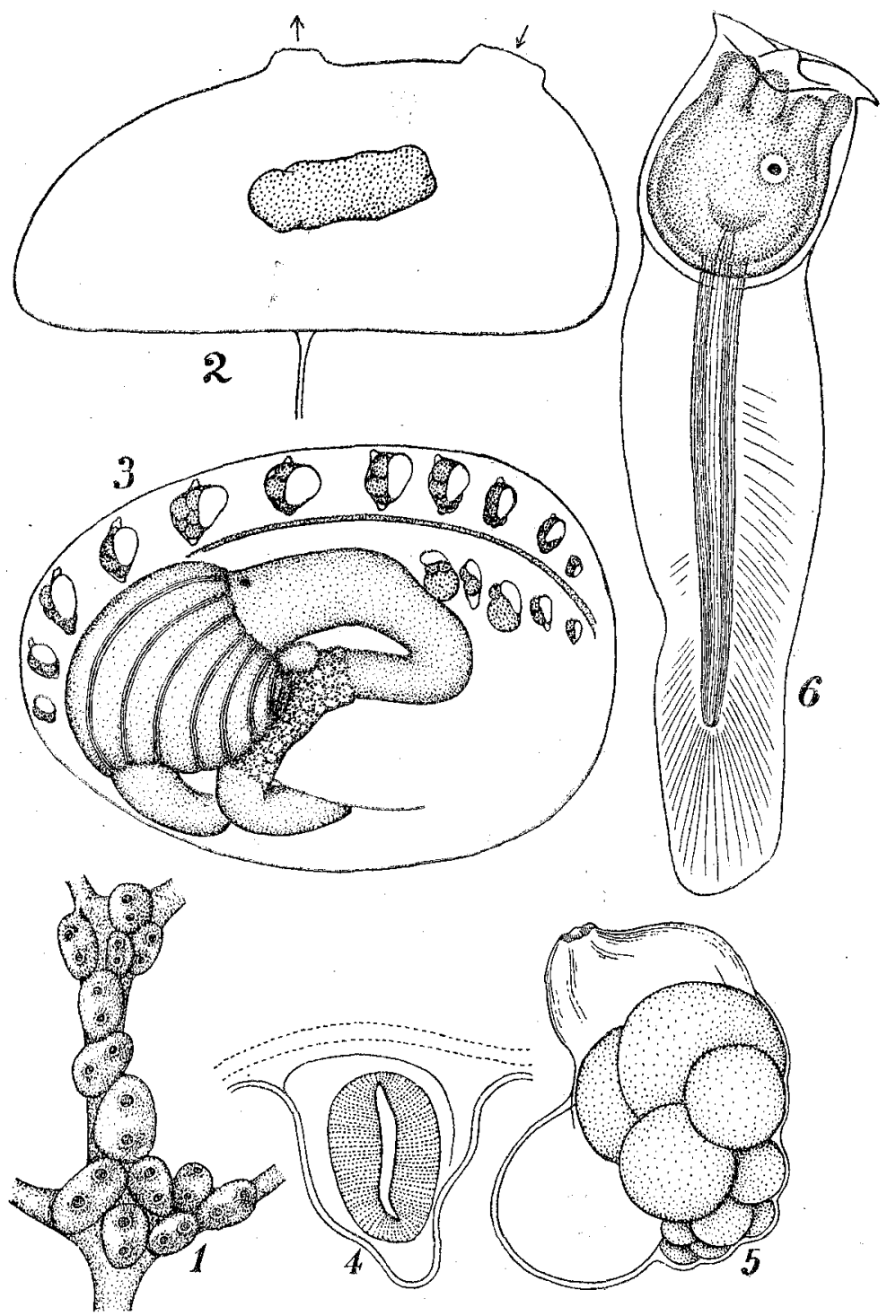

Fig. 4. Tolyzou pacifica n. sp. 1-Group of ascidians; 2-Right side of the mantle body; 3-Ventral side of the mantle body; 4 -Ciliated Groove, $\times 75$; 5 Gonad, $\times 75$; 6-Larva, $\times 45$.

Branchial sac: Stigmata rows 12 , stigmata very long and bridged by parastigmatic vessel, showing the following arrangement between 3 longitudinal vessels in one specimen: $\mathrm{D} \quad 8 \quad 7 \quad 7 \quad 8 \quad 13 \quad \mathrm{~V}$. Tentacles ca. 16. Ciliated groove a longitudinal slit.

Alimentary system: Alimentary canal occupies the ventral side of the 
body. Stomach large, with 15 plications on the surface and a conspicuous coecum in the pyloric portion. The proximal portion of the intestine is slightly thicker than the distal portion. Anus plainly margined. Circum-intestinal gland distinct.

Gonad: Maximum numbers in the present material 5 on the left and 11 on the right side. Each gonad consists of a round testicular follicle and several ova. About 30 embryos in various stages of development found contained in the atrium. of some zooids. Trunk of larva $0.6 \mathrm{~mm}$ in length and with 8 ampullae.

Remarks: This species closely resembles $P$. vesiculiphora ToкIOKA found in Akkesi Bay in Hokkaich. The characteristics differentiating the former from the latter are: 1) the dorso-ventrally compressed appearance of the body and 2) the presence of more stigmatarows (12 instead of 9 - 10 ) in the fomer.

\section{Styela partita (STMPSON) 1852}

(Fig, 5; PI. XT, Figs, 1-4)

Many small specimens attached on an oyster shell, of which the largest one measures $22 \mathrm{~mm}$ long $\times 16 \mathrm{~mm}$ wide, while the smallest one is only $4 \mathrm{~mm}$ long $\times 2 \mathrm{~mm}$ wide. Body roughly oval; branchial aperture terminal or subterminal, atrial aperture situated near it. Both apertures 4-lobed and not projected out strongly. Test thin and leathery, but strong, reddisl-brown in many specimens, although it may be grayish with a yellowish orange or brownish tint near the apertures in some individuals. Inner surface of test grayish brown. Surface of test varies in appearance from nearly smooth to somewhat wrinkled. Test of smaller specimens usually divided into many small areas by irregularly arranged grooves. The region surrounding both apertures is strongly grooved in all specimens. Smaller specimens attached by their whole ventral side, while larger ones attached by the ventro-posterior side. Mantle yellowish white, with many endocarps on the inner surface, especially on the right side. Atrial tentacles absent.

Branchial sac: Number of inner longitudinal vessels:

(15 $\mathrm{mm}$ long individual)

$\begin{array}{llllllllllll}\text { left } & \mathrm{D} & 1 & (13) & 4 & (13) & 4 & (14) & 4 & (10) & 3 & V . \\ \text { right } & \mathrm{D} & 4 & (14) & 4 & (14) & 5 & (14) & 4 & (10) & 3 & \mathrm{~V} .\end{array}$

(22 $\mathrm{mm}$ long individual)

$\begin{array}{llllllllllll}\text { left } & \mathrm{D} & 5 & (15) & 10 & (12) & 9 & (11) & 11 & \text { (ca. 5) } & ? & \mathrm{~V} \\ \text { right } & \mathrm{D} & 8-9 & (8) & 8 & (11) & 9 & (12) & 8 & \text { (5) } & 6 & \mathrm{~V}\end{array}$




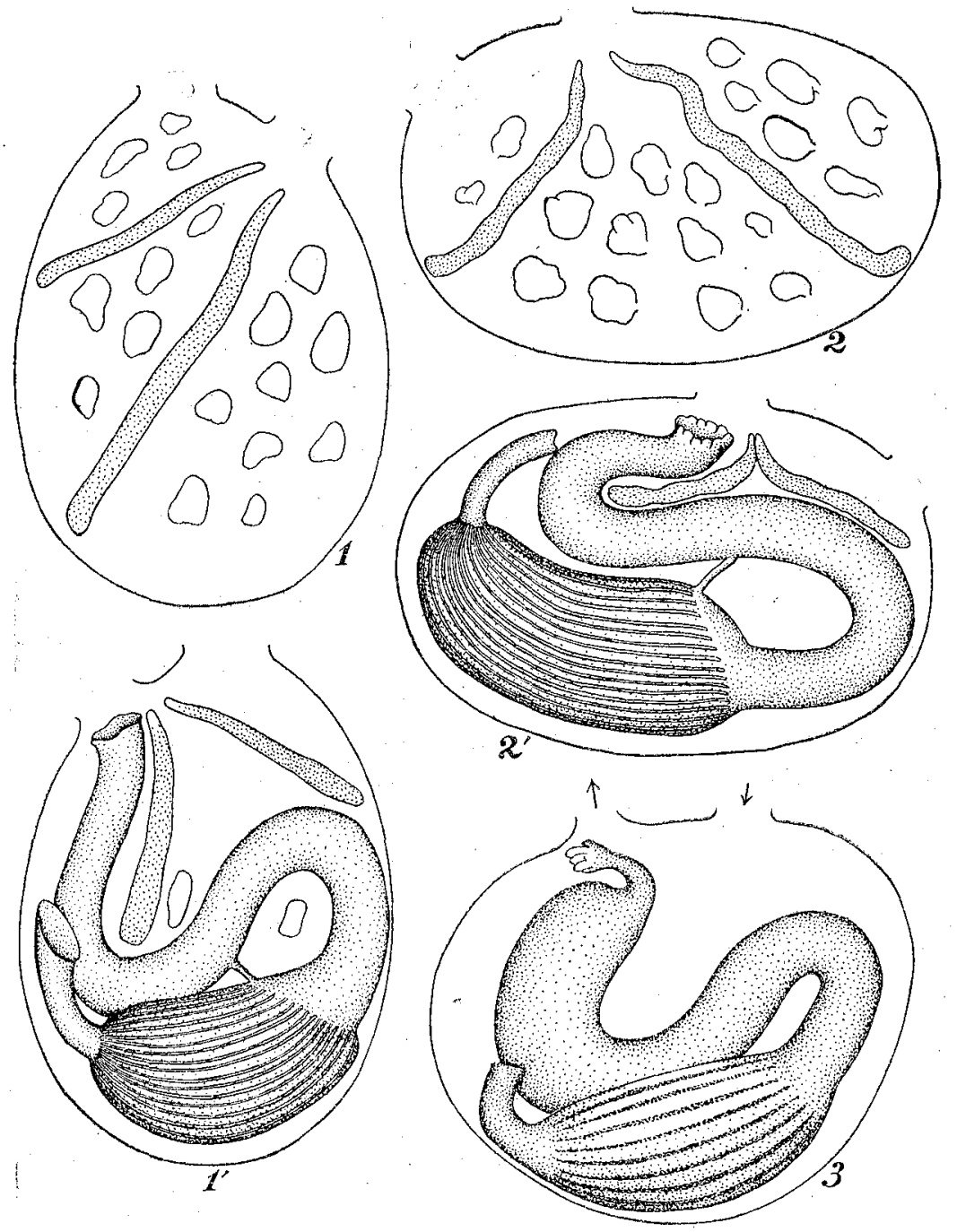

Fig. 5. Styola partita (STYMPson). 1,1'-22 mm long specimen; 1-Right half from inside; 1'-Left half from inside; $2,2-15 \mathrm{~mm}$ long specimen; 2-Right half from inside; 2 -I.eft half from inside; 3-Left half from inside, $9 \mathrm{~mm}$ long specimen.

Parastigmatic vessel present. About 5 stigmata in a mesh. Tentacles 40-60, excluding minute ones; large and small ones alternate rather irregularly. Ciliated groove simple U-shaped. In many specimens the peribranchial cavity contains a number of parasitic copepods.

Alimentary system: In smaller individuals alimentary canal occupies nearly the whole left side. Oesophagus very short, stomach elongate, with 17- 
18 plications on one side. Pyloric coecum absent, Intestine figures a S-like course. Anus lobated.

Gonad: Two long gonads on each side; the posterior one on the left side lies in the 2nd intestinal loop.

\section{Styela plicata (LesueUR) 1823}

Three specimens, $18-37 \mathrm{~mm}$ in length, attached to the substratum by posterior portion. Branchial aperture subterminal or terminal, atrial aperture situated near it. Colour of test varies from milky white to pale grayish brown. Test thick and irregularly grooved; and cartilaginous, although exceptionally it is rather hard. Apertures 4mlobed and marked each with 4 purplish browncolour bands which rapidly fade towards the basal portion. Mantle fleshy orange in colour, with many endocarps on the inner surface.

Branchial sac: Inner longitudinal vessels as follows:

(37 $\mathrm{mm}$ long individual)

D $\quad 3$ (13) $\quad 6 \quad(15) \quad 5 \quad(15) \quad 5$ (11) 4 V.

$(27 \mathrm{~mm}$ long individual)

$\begin{array}{llllllllllll}\text { left } & D & 3 & (15) & 4 & (13) & 4 & (14) & 3 & (10) & 3 & V \\ \text { right } & \mathrm{D} & 3 & (13) & 4 & (14) & 4 & (15) & 4 & (10) & 3 & \mathrm{~V} .\end{array}$

Tentacles ca. 25, excluding minute ones. Ciliated groove C- or horse-shoeshaped, with anterior ends curled in. Many parasitic copepods in the peribranchial cavity.

Alimentary system and Gonad: Oesophagus very long. Intestine with follicular appendages. Gonads 6-7 on the right and 2 on the left side. The left posterior gonad is surrounded by the 2 nd intestinal loop. Testicular follicles roundish in immature individuals, but elongate in mature ones. Gonad undevelopet in $18 \mathrm{~mm}$ long individual.

\section{Styela plicata forma tenuis n. $\mathrm{t}$.}

(Fig, 6)

One specimen, $49 \mathrm{~mm}$ long $\times 27 \mathrm{~mm}$ wide, is found in the material. Body oval, $31 \mathrm{~mm}$ long, with the thin posterior peduncular portion $18 \mathrm{~mm}$ in length. This specimen seems to be grown on the sandy bottom, since a mass of sand is attached to the end of the peduncle. Branchial aperture subterminal, atrial aperture situated near it. Test pale purplish-gray in colour and very thin, but tough. Surface rather smooth, with several faint grooves. Eight purplish- 

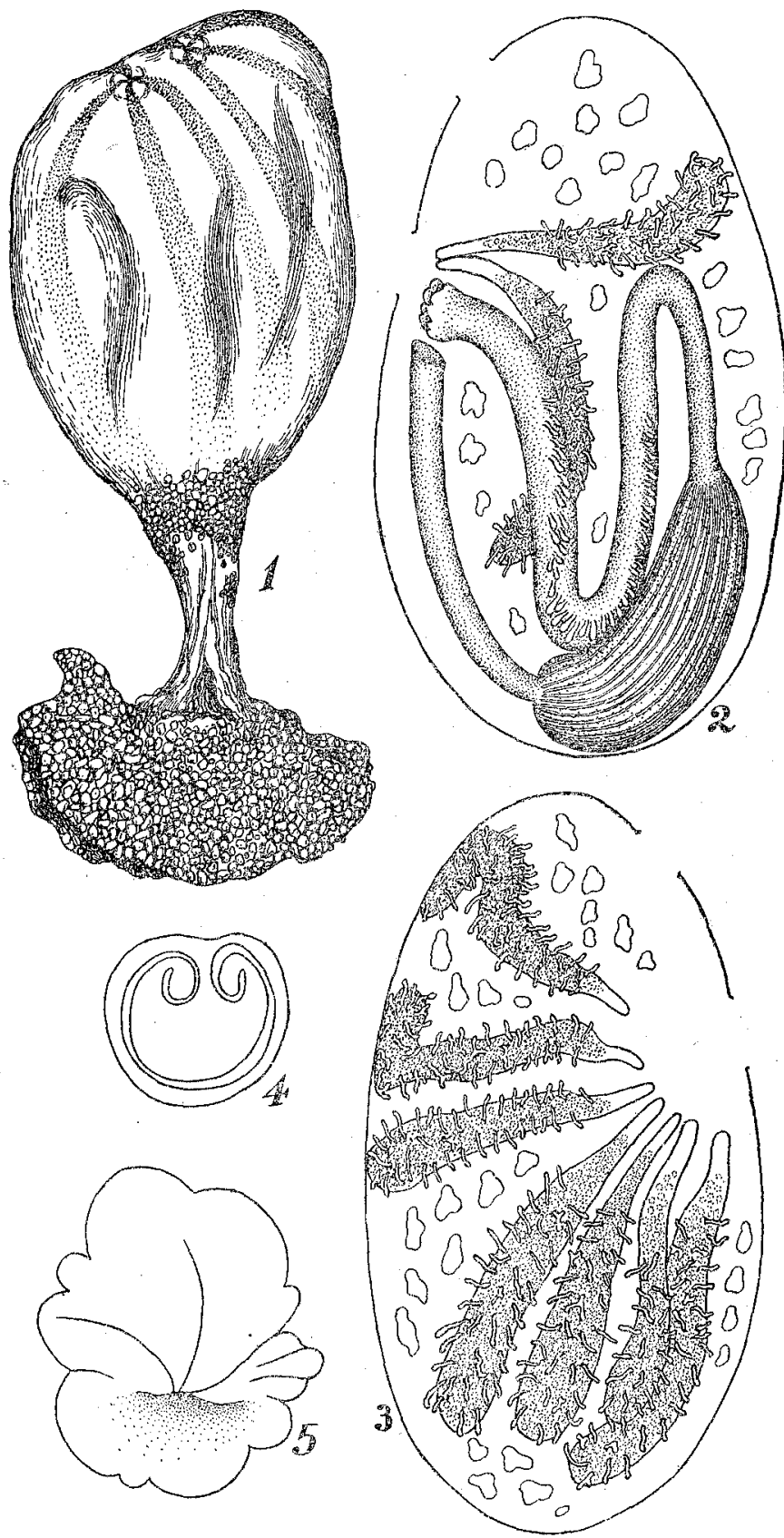

Fig. 6. Styolu plicata f. tenum in. f. 1-Entire animal; 2 -Left half from inside; 3-Right hallf from inside; 4 -Ciliated groove; 5-Anus. 
brown longitudinal bands run on the test and converge anteriorly to the apertures, 4 on each one. Mantle orange-brown, with many endocarps on the inner surface. Many parasitic copepods in the peribranchial cavity. Atrial velum present, but no atrial tentacles.

Branchial sac: Inner longitudinal vessels arranged as follows:

$\begin{array}{llllllllllll}\text { left } & \mathrm{D} & 9 & (10) & 13 & (17) & 9 & (16) & 8 & (11) & 6 & \mathrm{~V} \\ \text { right } & \mathrm{D} & 8 & (11) & 10 & (20) & 8 & (17) & 6 & (13) & 5 & \mathrm{~V}\end{array}$

Parastigmatic vessels present. Five to eight stigmata in a mesh. Tentacles 38 , arranged roughly: large-small-medium-small-large. Ciliated groove Ushaped, with anterior horis strongly curled in.

Alimentary system: Oesophagus very long. Intestine with follicular appendages. Anus lobated.

Gonad: Seven gonads on the right, 2 on the left side, the left posterior gonad in the 2nd intestinal loop. Testicular follicles elongate.

Renarks: As the internal structure of the present specimen is exactly the same as that of S. plicata, I prefer to treat the specimen as a peculiar pedunculate form of $S$. plicata, which differs from the type in the presence of a distinct peduncle and in the thin and smooth appearance of the test. Of these characteristics, the latter seems to be more pronounced than the former.

\section{Styela isibasii n. sp.}

(Fig. 7; Pl. XI, Fig 5)

A specimen, $33 \mathrm{~mm}$ long $\times 21 \mathrm{~mm}$ wide, attached to an oyster she1l. Body oval, attached by the posterior end. Branchial aperture terminal, atrial aperture situated near it. Both apertures 4-lobed and hardly discernible. Test light greenish-brown and very hard, and giving the specimen an appearance resembling $S$. plicata. It is $2 \mathrm{~mm}$ thick in some portions. The inner surface coloured somewhat brownish. Mantle yellowish and muscular. Atrial tentacles absent. Endocarps found on the inner surface of the mantle. The peribranchial cavity harbours a parasitic (?) amphipod.

Branchial sac: Inner longitudinal vessels arranged as follows:

$\begin{array}{llllllllrlll}\text { left } & \mathrm{D} & 7 & (20) & 6 & (21) & 9 & (24) & 7 & (20) & 7 & \mathrm{~V} \\ \text { right } & \mathrm{D} & 7 & (18) & 10 & (18) & 9 & (24) & 10 & (20) & 5 & \mathrm{~V}\end{array}$

Tentacles ca. 40. Ciliated groove U-shaped.

Alimentary system: Oesophagus long. Stomach with longitudinal plications. Intestine with follicular appendages. Anus lobated. Four endocarps in the intestinal loop. 

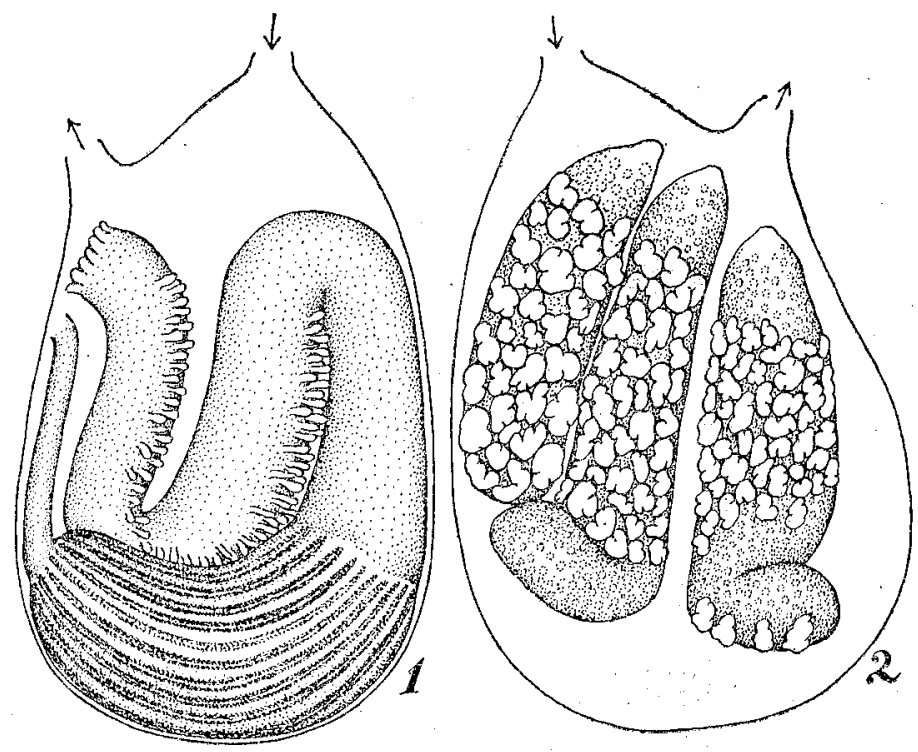

Fig. 7. Stych isibasii n, sp. 1-Left half from inside; 2-Right half from inside.

Gonad: Three thick gonads on the right side, none on the left. Testir cular follicles rather elongate and clustered in the middle part of each gonad,

\section{Styela clava HERDMAN 1881}

(PI. XI, Figs. 6 \& 6.)

A large specimen, $110 \mathrm{~mm}$ in length including the peduncle, and two small young onse, 10 and $35 \mathrm{~mm}$ long respectively, attached to an oyster she11. Descriptions of these small specimens follow :-

Body elongate, attached by the posterior end. Both apertures terminal and 4-jobed. Peduncle hardly discernible. The anterior part around the apertures furnished with many whitish irregular prominences, the rest of the test leathery and longitudinally wrinkled, whitish-brown in colour and marked faintly with some reddish tint. Ciliated groove C-shaped. No specimen has developed gonad.

\section{Haloc ynthia roretzi (DRASCHE) 1884}

(Fig. 8)

A small immature individual, $30 \mathrm{~mm}$ long $\times 17 \mathrm{~mm}$ wide, found on an oyster shell. As OKA (1935) describes the external appearance of an immature 
individual, I wish to give here my observations on the internal structure of the present specimen, with illustrations.

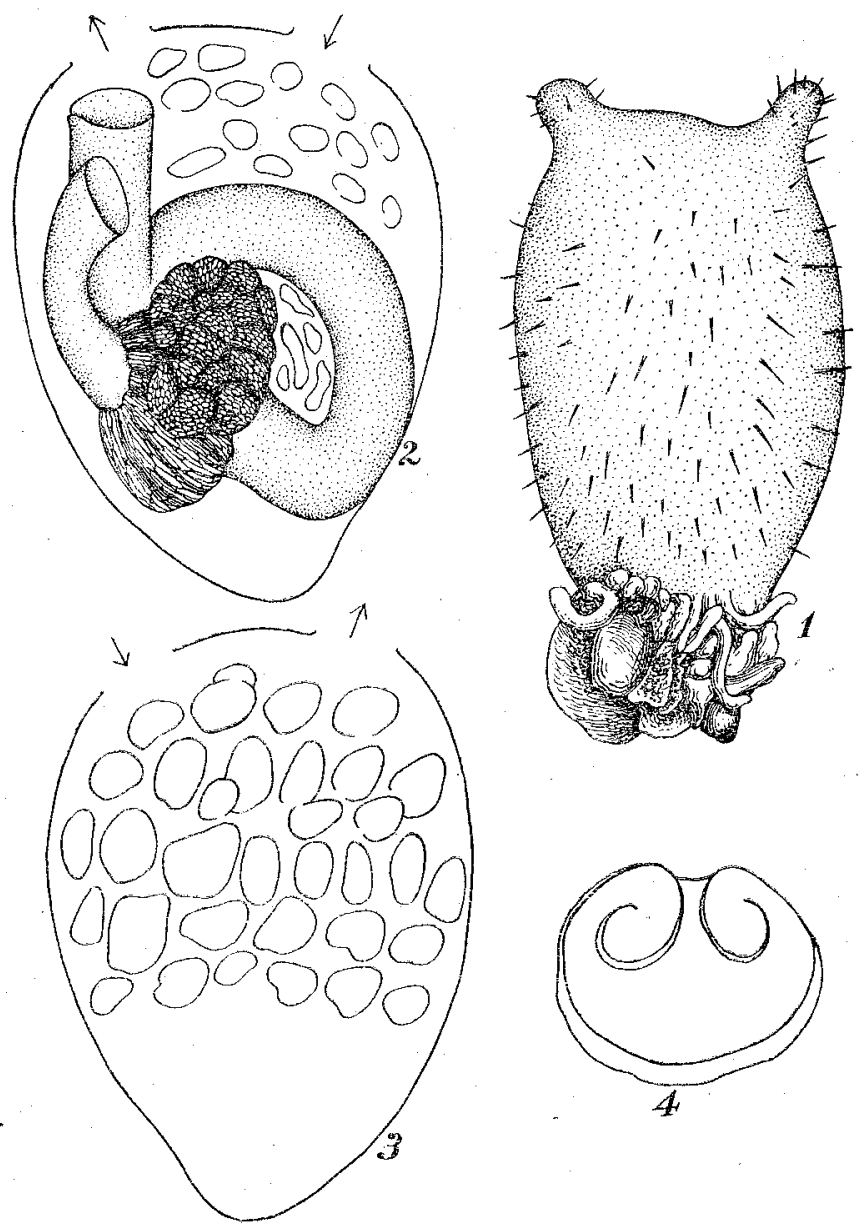

Fig. 8. Halorynthia roreta (DRAGCHE) juv. 1-Entire animal ; 2-Left half from inside; 3-Right half from inside; 4-Ciliated groove.

Test reddish-orange and sparsely armed with spines which are shorter than $1 \mathrm{~mm}$. Inner longitudinal vessels of the branchial sac arranged as follows:

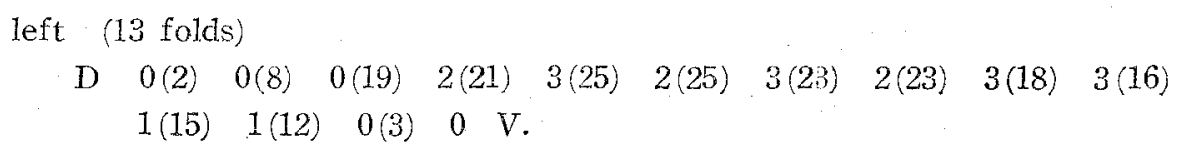




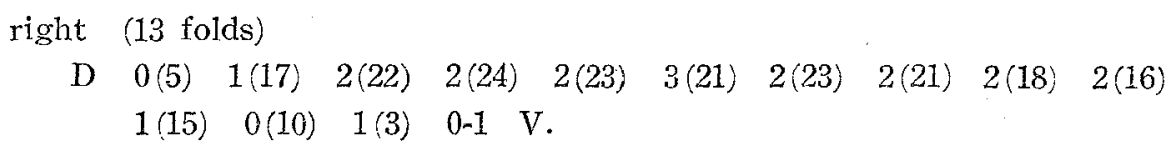

Parastigmatic vessels present. Five to six stigmata in a mesi. Tentacles 15 , excluding minute ones; branches in 2 orders, of which those of the 2nd order are very sparse. Ciliated groove U-shaped, with terminals strongly curled in. Liver yellowish. Intestine faintly purplish in colour. Anus plainly margined. Gonad not yet developed.

\section{Eugyra sp. (?) (PI. XI, Fig. 7)}

A small, $9 \mathrm{~mm}$ long, oval ascidian is found on an oyster shell. Test very soft, both apertures situated at the anterior end of the body. The inner side is mutilated, which makes the identification of the specimen very difficult. Very probably, however, the present specimen is a molgulid, belonging to the genus Eugyra, judging from the general appearance of the body which can hardly be assigned to any genus of other solitary ascidians.

\section{EXPIANATION OF PLATE XI.}

Fig. 1 . . Styela partita (STIMPSON), Right side of the $22 \mathrm{~mm}$ long specimen.

Fig. 1'... , " ", ; Ciliated groove of the $22 \mathrm{~mm}$ long specimen.

Fig. 2... " " $\quad$ " , Dorsal side of the $15 \mathrm{~mm}$ long specimen.

Fig. 2, . , , , , , Ciliated groove of the $15 \mathrm{~mm}$ long specimen.

Fig. 3.. , , , , , Right side of the $9 \mathrm{~mm}$ long specimen.

Fig. 4... , , , , , , $14 \mathrm{~mm}$ long specimen.

Fig. 4, .. , , , , , , Left half from inside, $14 \mathrm{~mm}$ long specimen.

Fig. 5 . . Styela isibasii n. sp., Right side of the animal.

Fig. 6 . . Styela clava Herdman, Right side of the $35 \mathrm{~mm}$ long specimen.

Fig. 6'.. , , , , Ciliated groove of the $35 \mathrm{~mm}$ long specimen.

Fig. 7 . Eugyra sp. (?). 


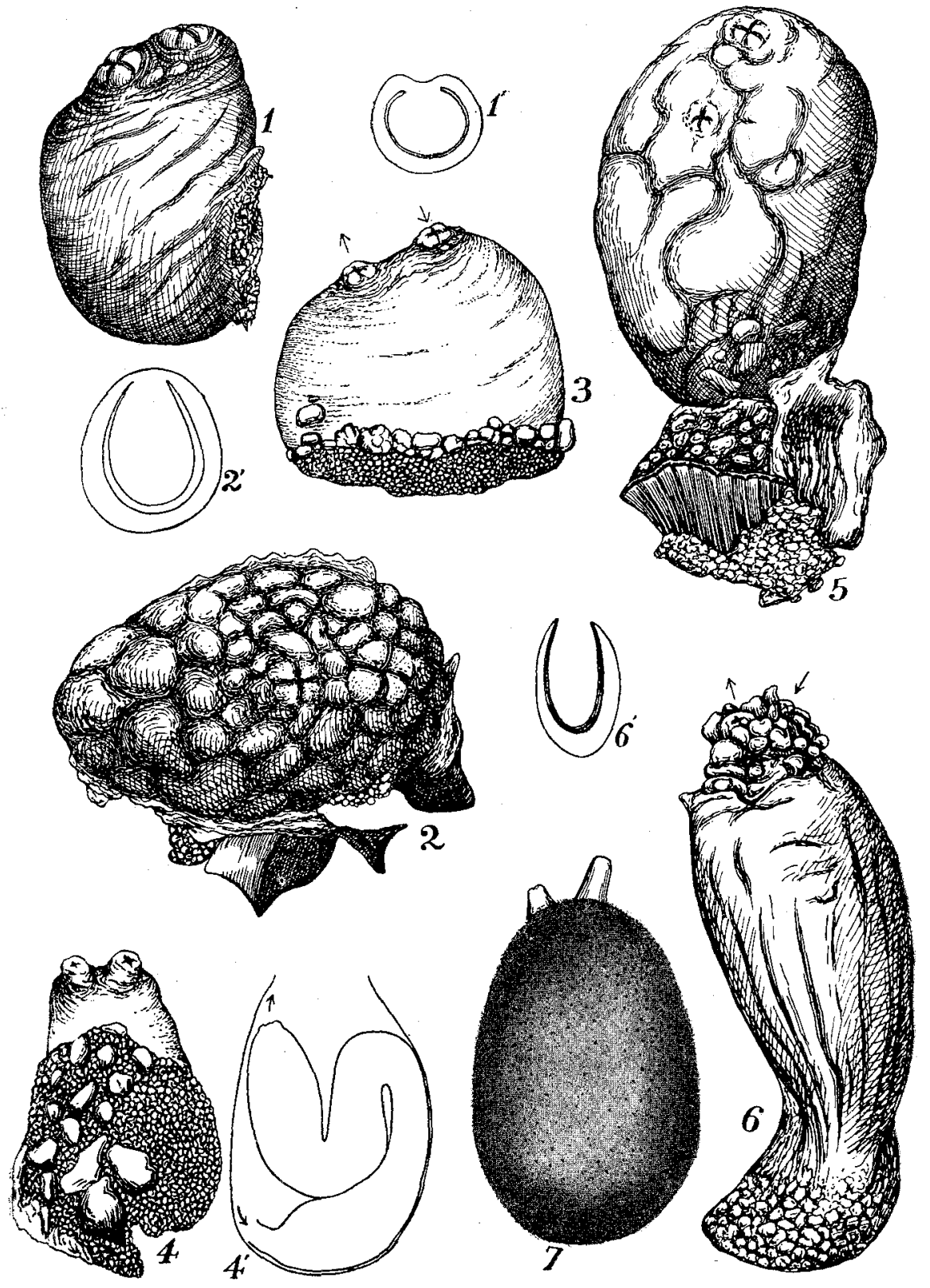

T. Tokioka: Japanese Ascidian Fauna, IV 